\title{
Resenha
}

\section{Juventude e projetos vitais na sociedade contemporânea'}

\author{
Youth purpose in contemporary society
}

\author{
Cristina Satiê de Oliveira PÁTARO²
}

Na sociedade contemporânea, as possibilidades de escolha dos sujeitos apresentam-se de modo bem mais ampliado do que o eram nas sociedades tradicionais, de modo que as perspectivas de futuro tornaram-se menos previsíveis, permeadas pela multiplicidade e pelas incertezas que caracterizam a própria contemporaneidade. Nesse contexto em que - na constituição da trajetória, da biografia e da(s) identidade(s) -, as decisões e escolhas dos sujeitos mostram-se tão relevantes quanto as determinações e imposições da sociedade, a construção de um projeto de vida que possa servir de orientação e dar um sentido ao juízo e às ações dos sujeitos torna-se fundamental.

Diante dessa constatação, como educar a(s) juventude(s)? Sendo a juventude uma fase da vida na qual as mudanças ocorrem de modo mais intenso e em que o sujeito deve aprender a lidar com a tensão permanente entre continuidade e ruptura, constituindo o senso de identidade e de permanência, como fomentar a construção de projetos de vida pelos jovens?

Essas são questões que permeiam a obra"O que o jovem quer da vida?", do psicólogo norte americano William Damon, pesquisador da Universidade de Stanford, diretor do Stanford Center on Adolescence e estudioso do desenvolvimento humano, em especial do desenvolvimento moral. Em seu livro, que traz os primeiros resultados e discussões de pesquisas realizadas nos últimos anos, o autor volta-se especificamente para a formação moral da juventude, partindo do princípio de que muitos dos jovens que parecem prosperar - permanecendo longe de problemas e cumprindo com as atribuições que a sociedade lhes confere -, estão, na verdade, sem rumo, não tendo ainda encontrado algum propósito ao qual dedicar suas vidas.

Damon apresenta o conceito de "projeto vital", compreendido como uma intenção de alcançar algo que é significativo tanto para o eu quanto para o mundo além do eu. Os projetos vitais são, portanto, construídos com base em valores morais, e expressam um engajamento do sujeito em fazer a diferença no mundo, a partir de seus interesses e potencialidades, em uma postura otimista, persistente e empreendedora. Embora a tradução direta do conceito nos conduza ao termo"propósito", o trabalho de Damon chega ao Brasil sob a denominação de "projeto vital", por ser o termo mais apropriado à definição posta nos estudos desenvolvidos pelo autor. Nesse sentido, é necessário ressaltar que o projeto vital se caracteriza não apenas por atribuir um sentido ético à vida do sujeito, mas por ser também fundamental, essencial, central em seus interesses e em sua identidade.

$\boldsymbol{v} \boldsymbol{\nabla} \boldsymbol{v}$

1 Damon, W. (2009). O que o jovem quer da vida? São Paulo: Summus.

2 Universidade Estadual do Paraná, Faculdade Estadual de Ciências e Letras de Campo Mourão, Departamento de Pedagogia. Av. Comendador Norberto Marcondes, 733, Centro, 87303-100, Campo Mourão, PR, Brasil.E-mail: <crispataro@gmail.com>. 
A obra é organizada em sete capítulos. Inicialmente, o autor busca contextualizar a(s) juventude(s) na contemporaneidade, por meio de discussões, questionamentos e resultados de pesquisas acerca das vivências, preocupações e expectativas dos jovens, na intenção de demonstrar a importância dos projetos vitais para os sujeitos.

Os três capítulos que se seguem são dedicados à apresentação do conceito de projeto vital e das características dos jovens que os constroem. Assim, o segundo capítulo do livro discute especificamente os projetos vitais, seus pressupostos e suas bases psicológicas, a partir do diálogo com diferentes pesquisadores do campo do desenvolvimento humano e da psicologia moral. No terceiro capítulo, são destacadas características de quatro diferentes grupos de jovens, identificados por Damon a partir de suas pesquisas e de entrevistas realizadas com jovens norte-americanos, e que refletem o modo como o sujeito se posiciona diante dos projetos vitais. São eles: os desengajados, os sonhadores, os superficiais e os jovens com projetos vitais. Já no quarto capítulo, Damon expõe o perfil e a história de quatro jovens que possuem projetos vitais, no intuito de indicar elementos, experiências e posturas que os diferenciam.

Os três últimos capítulos do livro têm como objetivo realizar apontamentos e reflexões acerca de uma educação para as crianças e jovens que contribua para a construção de projetos vitais. O autor traz orientações voltadas para as diferentes instâncias que devem atuar na formação moral das novas gerações, versando sobre contribuições que podem advir dos familiares, da instituição escolar, da comunidade e, inclusive, da esfera pública, em vista da criação de uma cultura de projetos vitais para todos os jovens. A proposta de Damon, nesse sentido, é a de apontar possibilidades de superação da cultura do imediatismo que vem caracterizando a sociedade contemporânea, e que acaba valorizando preocupações imediatistas e objetivos de curto prazo pautados na lógica da competição, da autopromoção, do status e do ganho material.
Para além de orientações aos jovens, aos familiares, aos educadores e aos pesquisadores envolvidos com a juventude, as considerações e discussões suscitadas pela obra de Damon representam contribuições importantes para os estudos sobre a moralidade humana e o desenvolvimento da identidade moral. Ao entender o projeto vital como um elemento vinculado à moral e à identidade do sujeito, permeado tanto por preocupações significativas para o mundo mais amplo quanto para o próprio sujeito, o trabalho de Damon permite considerar a relevância de aspectos pessoais e idiossincráticos no julgamento e na ação moral, bem como no processo de construção da moralidade, o que acaba por colocar em cheque concepções racionalistas que encaram a moral em uma perspectiva universal, impessoal e abstrata.

As ideias expostas nesse livro, assim como todo o trabalho que vem sendo desenvolvido por Damon nos últimos anos, inserem-se nas discussões da psicologia positiva, movimento iniciado ao final da década de 1990 a partir, sobretudo, do trabalho do norte-americano Martin Seligman, cujo enfoque consiste em investigar as possibilidades, as potencialidades e os aspectos positivos do ser humano. No que tange aos estudos sobre a juventude, essa perspectiva faz-se especialmente relevante, contribuindo no sentido de superar a visão negativa que em geral é associada aos jovens tidos como naturalmente rebeldes, problemáticos e vivenciando uma fase de transição e de incompletude rumo à plenitude da vida adulta.

Por fim, cabe ressaltar que, no Brasil, vêm sendo realizadas as primeiras pesquisas com base no conceito de projeto vital da juventude. Tais investigações certamente trarão grandes contribuições não apenas para os estudos da psicologia moral, mas também para a compreensão dos jovens brasileiros, possibilitando importantes implicações aos processos educativos voltados para a juventude.

Recebido em: 8/9/2011 Aprovado em: 10/5/2012 